International Research Journal of Management, IT \& Social Sciences
Available online at https://sloap.org/journals/index.php/irjmis/
Vol. 7 No. 1, January 2020, pages: 37-44
ISSN: 2395-7492
https://doi.org/10.21744/irjmis.v7n1.820

\title{
Virtual Reality and 21st Century Education
}

CrossMark

Yeneri Carolina Rivas ${ }^{a}$

Patricio Alfredo Vallejo Valdivieso ${ }^{\text {b }}$

Marcos Alejandro Yanez Rodriguez ${ }^{c}$

Article history:

Received: 18 November 2019

Accepted: 27 December 2019

Published: 09 January 2020

\section{Keywords:}

educational technology;

generation;

innovation;

teaching-learning process;

virtual reality;

\begin{abstract}
Virtual Reality (RV), is one of the technological tools of the 21st century applied in the field of education and has increased significantly the use of it, to achieve the expected learning in students, the present This article aimed to demonstrate that VR as an innovative tool in 21st-century education contributes significantly to the teaching-learning process of students and teachers. It has worked based on a descriptive methodology-documentary, applying the analysis and interpretation of content, was limited to the review of articles published in digital journals, located in different databases, among the results there is a challenge that education should Assume and actively incorporate virtual reality, such as the technology that is a fundamental part of the daily life of the new generations, as an educational paradigm focused on the student, where it is intended to be autonomous and independent in the generation of learning.
\end{abstract}

International research journal of management, IT and social sciences (C) 2020. This is an open access article under the CC BY-NC-ND license (https://creativecommons.org/licenses/by-nc-nd/4.0/).

\section{Corresponding author:}

Yeneri Carolina Rivas,

Pontificia Universidad Católica del Ecuador Sede Manabí, Portoviejo, Ecuador.

Email address: yrivas8879@pucem.edu.ec

\footnotetext{
a Pontificia Universidad Católica del Ecuador Sede Manabí, Portoviejo, Ecuador, https://orcid.org/0000-0001-5002-2820

b Pontificia Universidad Católica del Ecuador Sede Manabí, Portoviejo, Ecuador, https://orcid.org/0000-0003-3248-7864

Pontificia Universidad Católica del Ecuador Sede Manabí, Portoviejo, Ecuador, https://orcid.org/0000-0003-3683-8481
} 


\section{Introduction}

Education in the 21 st century is a challenge that must be assumed with responsibility expressed in the need for a teaching that is solid and flexible in turn that adapts to the times. The paradigms, approaches, traditional trends that are based on the use of texts in the classroom are questioned, memorizing facts, stories, concepts have lost meaning, if it does not allow reasoning, analysis, argumentation, the education process is emphasizing in which the student develops intellectual, moral and physical skills that in many cases, can be experiential oriented by the teacher.

Students must learn to combine and interpret information creatively, solve problems. The technology of Virtual Reality (VR) is a tool that the teacher can apply as a didactic methodology in the education of the 21 st Century, which can serve to motivate and maintain the attention of students, through 3D or three-dimensional graphics Quality and interactive offered by virtual systems, unfortunately, one of the difficulties for the application of virtual reality (RV), in education is the price so high, this technology is not available to students and teachers.

Precisely, the programming language of virtual world modeling in three dimensions appears, which can be created by means of code in plain text files (VRML), lowering prices, making this technology more accessible to anyone who has a computer and Internet.

The objective of the research is to demonstrate that VR, as an innovative tool in 21st-century education, contributes significantly to the teaching-learning process of students and teachers. The methodology used is based on a descriptive methodology - documentary, applying content analysis as a technique for information processing.

\section{Materials and Methods}

The research design, which has been used is descriptive, the keywords were established for the search in different databases, both national and international with the aim of demonstrating that the RV as an innovative tool in the education of the 21 st century contributes significantly to the teaching-learning process of students and teachers.

The inductive-deductive method was used in the discourse, another of the methodologies used for carrying out the bibliographic research and direct observation.

\section{Results and Discussions}

During the last 30 years, different technologies have been implemented in education since 1980 with audio cassette, television, graphic audio system on the computer, interactive videos, web TV, virtual reality, simulation techniques 3D (González \& Chávez, 2011). Virtual reality has been specifically implemented a few years ago, this technological tool allows students to learn by doing, achieving in order to be, know and know-how, for this reason, it is important to rethink the organization of educational activities, through a system new educational in the virtual reality environment.

\section{Virtual Reality}

There are several definitions of what Virtual Reality (RV) means, one of them describes it as the human-machine interface, which gives the person the opportunity to delve into a 3-dimensional graphic simulation (3D) which generates a computer that allows you to navigate interacting in it in real-time (Pérez, 2011; Macías et al., 2018).

The RV is a simulation that generates a 3D computer, in which the avatar or user can see and manipulate the content, one of its characteristics is that it generates a multisensory and interactive response which allows an immediate sensation to the real (León, 2012; Alava \& Martinez, 2019). The multisensory information provided by the RV, is the sound, vision and touch, with the intention that the user can feel that it is in the selected place, an image about virtual reality is shown in Figure 1. 


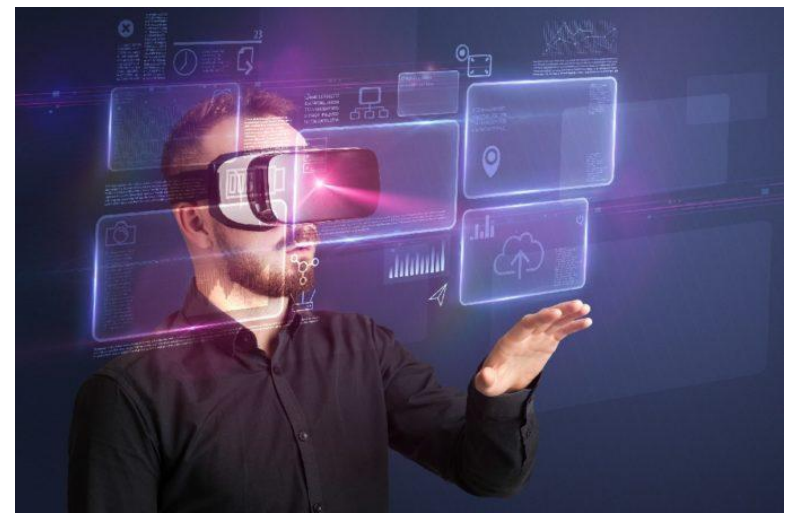

Figure 1. Presentation of virtual reality

Source: (Dir \& ge The business space for directvos and dicesores, 2017)

Until recently, software as hardware, necessary for the RV was very expensive, however, at present it is easier since the prices of the equipment or devices have been reduced, making many people and educational institutions have the possibility to explore in the world of VR from their personal devices.

Figure 2 shows the elements to understand the definition of RV, they are the following: simulation, generated by threedimensional computers, perception and finally it is interactive, according to (Ortega et al., 2003).

\section{Simulation: it is the ability to represent the system as close as possible to reality, in such a way that the person who makes one of the system convinces himself of that reality, of course that he is guided by rules.}

\section{IInteraction: is the ability to maintain control of the system created so that the information sent by the person making use of the RV produces a change in the artificial world.}

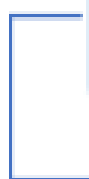

\section{Perception: VR systems especially direct the senses (sight, hearing, touch) through external objects. Data gloves, display helmets}

Figure 2. Elements of virtual reality

According to the sources consulted, on VR, they coincide in what it means to immerse themselves in the $3 \mathrm{D}$ world, of what is observed and lived by feeling that objects leave the screen and with the feeling of approaching the person, these experiences generate knowledge in students, also allows you to understand abstract elements and complex phenomena that would otherwise be understood in a lower percentage, the RV allows you to experiment with the real world (Ortega et al., 2003).

Figure 3 shows the types of virtual reality according to the hardware you use.

Rivas, Y. C., Valdivieso, P. A. V., \& Rodriguez, M. A. Y. (2020). Virtual reality and 21 st century education. International Research Journal of Management, IT and Social Sciences, 7(1), 37-44. https://doi.org/10.21744/irjmis.v7n1.820 


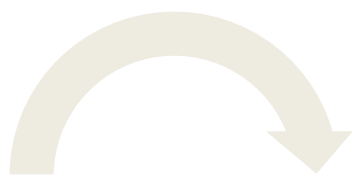

Desktop RV: It is used by a person or a small group of people, the virtual environment is projected through a computer and people interact using it can be the mouse to navigate in 3D or it can be the data gloves.
Immersion RV: The person uses an RV helmet or lenses, motion sensors and data gloves this allows the user to achieve a high percentage of immersion in reality. (Urquiza, Auria, \& Daza, 2016).

Figure 3. Types of virtual reality according to hardware

\section{Virtual communities Virtual}

Worlds can be designed for a single person called in this case user or for many simultaneous users. When that virtual world supports several users it gives rise to what is called the virtual community, the users that are part of this virtual community have a high cognitive level in the artificial world, in that simulated context these users can communicate with others, in the At the level of collaborative work, teaching and learning, this learning community changes the role of the teacher and the student since they become instructional and learning users, learning in the RV environment could be more significant (Jimenez et al., 2000; Aryani \& Rahayuni, 2016).

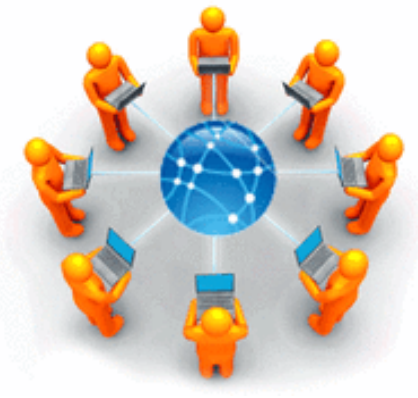

Figure: 4. Virtual communities

Source: https://www.tes.com/lessons/Z7oAqWYtaExdMg/comunidades-virtuales-de-aprendizaje

\section{Virtual reality devices}

In the area of vision use helmets or a mechanical arm, which supports the display that by turning it you can see the virtual world environment, in which the user is immersed, these devices produce the sensation of seeing a $3 \mathrm{D}$ image. The headphones are necessary to be able to listen to the sounds produced by the virtual environment, they are simple or conventional allow listening without identifying the location of virtual objects. The convolution simulates the location of the objects within the virtual environment. These devices are shown in Figure 5. 


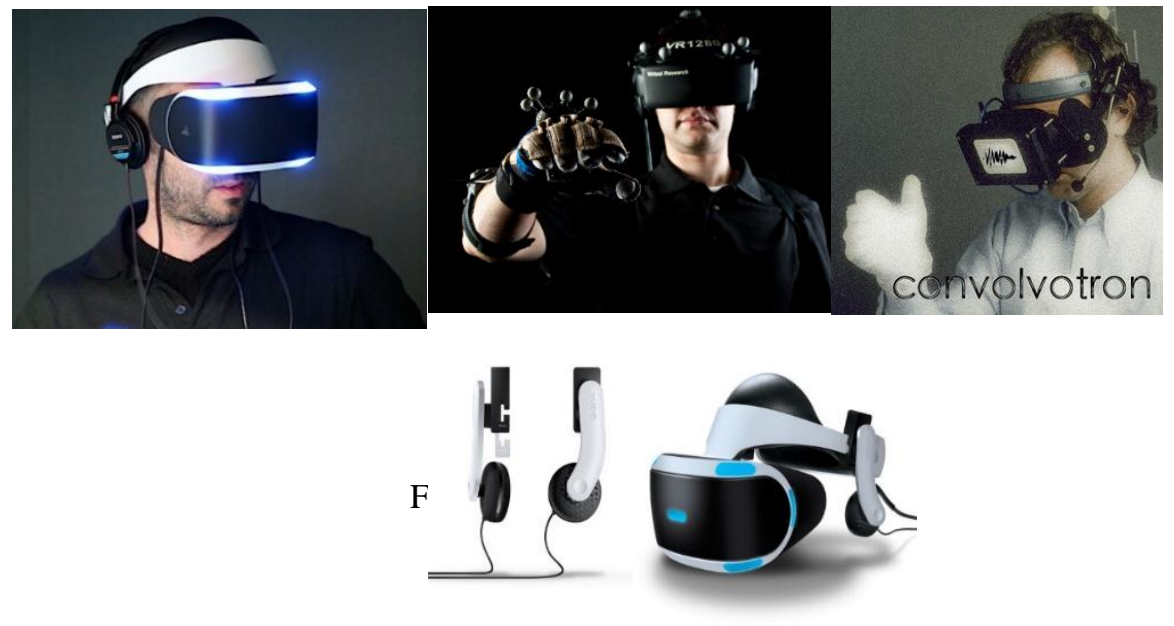

Figure 5. Helmet gloves convolvotron Source: (Globedia, 2014)

Currently, gloves and suits are being used in the RV as a means to interact in the virtual environment, they are input devices that help to get to know the computer, the actions of the users (Row, 1999).

\section{Virtual reality can be incorporated into education}

It is considered pertinent to know the concept or conception of ideal education to contrast it with the real one and becoming aware of the things that need to be modified. In the educational process, every effort is made to route, guide, guide, empower, develop or improve the intellectual, moral and physical faculties of the student; through the teaching process, which in many cases can be experiential oriented by the teacher, guide or tutor empowered for this purpose (Zambrano, 2005; Jain, 2017).

The incorporation of the RV, to the classrooms as innovation of the education of the XXI Century assuming a qualitative leap in the learning process in the different areas of knowledge, especially, in those that it is difficult to visualize the processes that have been studied. This technology makes it easy for teachers to explain complex processes (Urquiza et al., 2016).

The RV, is an appropriate technology for the teaching process, is due to the facility to capture the attention of students through immersion in virtual worlds that are related to the different branches of knowledge, which favors the learning of the container in any subject. Experiments carried out by Sherman \& Judkins (1998), according to Hilera et al. (1999), at the University of Washington it can be concluded that students, thanks to this technology, "can learn quickly and assimilate information consistent that through the use of traditional teaching technologies".

In the RV almost all the senses are used, the students not only read and see images through the RV helmet; They can also listen to the stories, music, sounds related to the subject of the subject they are studying. Through data gloves, students can even feel the texture, dimensions, and temperature of virtual objects that exist within that virtual world.

The RV, is becoming increasingly popular in educational institutions for its wide variety of applications, for example, the virtual museum that helps strengthen the study of history, the heritage of certain countries and art, also helps students to involve historical or fictional facts enriching and making their knowledge more meaningful, they can also do studies of the batteries that enter the body of humans and cause diseases, this technology used in the Education of the 21 st Century allows the abstract and intangible to pass To be concrete and manipulable. The RV has advantages in Education, including the delivery of information through channels, inclusion, valuing different learning styles and especially experiential and meaningful learning (Flores \& Avalos, 2014).

Innovation, advances, research and new technologies have generated changes and learning needs. Society has planned demands on education that requires teaching models that adapt to time and space. The ICTs offer a variety of possibilities for specific education according to the need of the students who want to be trained and according to the

Rivas, Y. C., Valdivieso, P. A. V., \& Rodriguez, M. A. Y. (2020). Virtual reality and 21 st century education. International Research Journal of Management, IT and Social Sciences, 7(1), 37-44. https://doi.org/10.21744/irjmis.v7n1.820 
content that they want to impart, therefore they are means that allow implementing new pedagogical models for teaching and learning (Olivar \& Daza, 2007).

Education in Ecuador for many years has taught a traditionalist model, focused on unidirectional education, making minimal use of the technological tools that have arrived in the country as a result of globalization. Many people can infer that VR tools are expensive and out of reach of students, but in reality, this technological gap has been agreed every day, according to the Ecuadorcifras.gob.ec government portal, there are approximately $53.9 \%$ of the population ( 5 years and older) has at least one activated cell phone, 11 points more than what was recorded in 2010 . In the rural area, the increase is 17.2 points in the last 5 years, as observed in Figure 9 and more than $47 \%$ use the internet continuously (Ecuadorencifras, 2015).

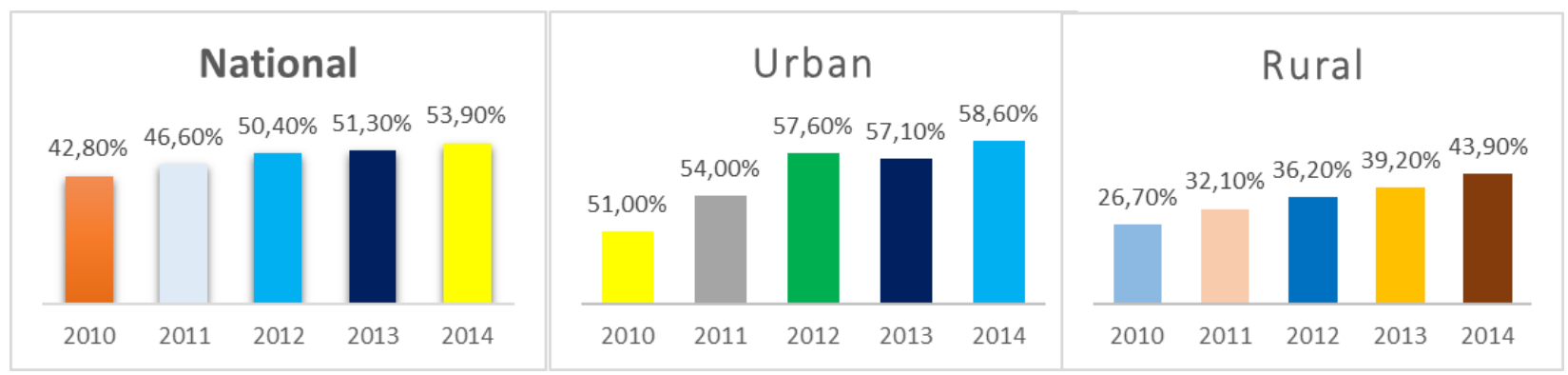

Figure 6. Percentage of people who have activated cell phone by area

Source: Ecuador in figures (2014)

Figure 7 shows the percentage of people who have used the internet by area in the country, showing the national, urban and rural areas.

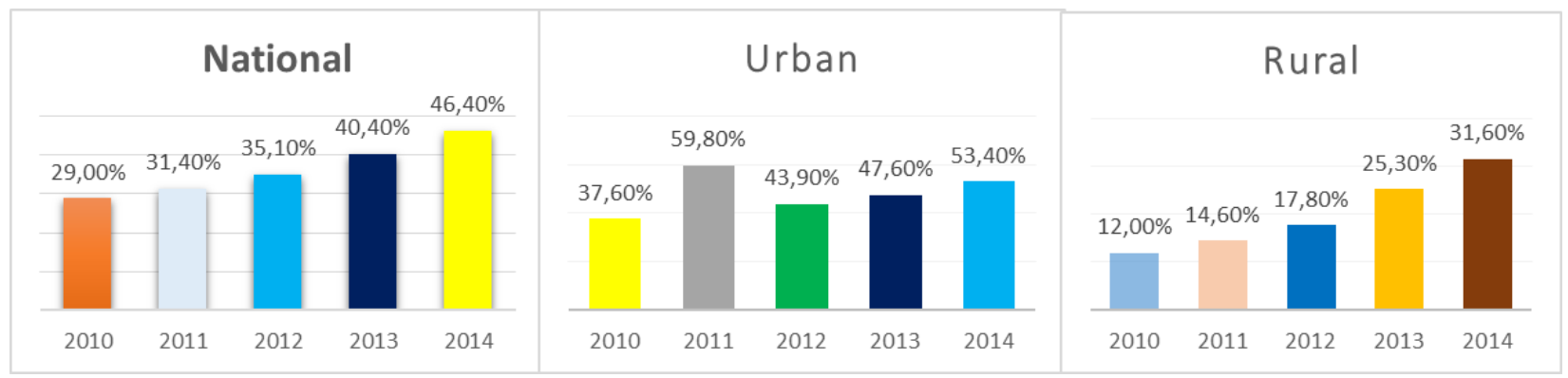

Figure 7. Percentage of people who have used the internet in the last 12 months by area

Source: Ecuador in figures (2014)

Technology brings benefits to the society of the 21 st century, but it is also necessary to know how to use it for educational purposes. The RV is the trend of this Century through which students can live an indescribable experience that in turn achieve experiential and meaningful learning.

\section{Conclusion}

The RV is a technological tool that allows simulating situations in different real-world spaces, especially in education, being a great help in the teaching-learning process, generating significant contributions in the teaching-learning process for both students and students. Teachers, being able to enter the Ecuadorian educational process.

It contributes to the achievement of constructivist learning, facilitating different alternatives for learning, giving students the opportunity to collaborate in their learning and significantly increasing their motivation and interest, being able to integrate it as a tool to achieve learning as long as it is trained to teachers about their use, handling of the devices and benefits that they bring to education. 
Conflict of interest statement

The authors declared that they have no competing interests.

Statement of authorship

The authors have a responsibility for the conception and design of the study. The authors have approved the final article.

Acknowledgments

The authors would like to thank the editor of IRJMIS for their valuable time, support and advice in completing the current study.

Rivas, Y. C., Valdivieso, P. A. V., \& Rodriguez, M. A. Y. (2020). Virtual reality and 21 st century education. International Research Journal of Management, IT and Social Sciences, 7(1), 37-44. https://doi.org/10.21744/irjmis.v7n1.820 


\section{References}

Alava, E. E., \& Martinez, M. E. M. (2019). Impact of teaching-learning process for brain. International Journal of Health Sciences, 3(1), 33-40. https://doi.org/10.29332/ijhs.v3n1.304

Aryani, I. G. A. I., \& Rahayuni, N. K. S. (2016). Innovation of teaching and learning english applied to animal sciences' student with the combination of computer media and audio visual. International Journal of Linguistics, Literature and Culture, 2(1), 1-7.

Dir \& ge The business space for directvos and dicesores. (2017). Obtained from Dir \& ge The managers' magazine: https://directivosygerentes.es/en-portada/quien-quien-la-realidad-virtual-espana

Ecuadorencifras. (2015). Information and Communication Technologies- ICT. Obtained from the National Institute of Statistics and Censuses: https://www.eficienterencifras.gob.ec >ecuador-en-figures

Flores, J., \& Avalos, P. (2014). Virtual reality an innovative technology applicable to the teaching process of engineering students. 6(2), 1-10. Retrieved from https://www.redalyc.org/pdf/688/68835725008.pdf

Globedia. (2014). Obtained from The collaborative newspaper: http://ec.globedia.com/juega-morpheus-cascorealidad-virtual-sony

González, A., \& Chávez, G. (2011). The Immersive Virtual Reality In Intelligent Learning Environments. Journal of communication and emerging technologies, 2(9), 122-137. Obtained from Available at: http://www.redalyc.org/articulo.oa?id=552556583008

Hilera, J., Otón, S., \& Matínez, J. (1999). Application of Virtual Reality in teaching through the Internet. Multimedia Documentation Notebooks, 8, 25-35. Retrieved from https://revistas.ucm.es >index.php> CDMU >article> download

Jain, P. (2017). Effect of online education trend on quality management. International Journal of Health Sciences, 1(1), 1-5. https://doi.org/10.21744/ijhs.v1i1.16

Jimenez, A., Luna, E., \& Villalobos, M. (2000). When and How to use Virtual Reality in Teaching. Iberoamericana de Informática Educativa (16), 26-36. Retrieved from https://dialnet.unirioja.es/servlet/articulo?codigo=4794517

León, R. (2012). Application of non-immense virtual reality for Agricultural Engineers. Agricultural Technical Sciences, 21(1), 69-71. Retrieved from http://scielo.sld.cu/pdf/rcta/v21n1/rcta13112.pdf

Macías, E. I. P., Cedeño, H. A. C., \& Chávez, G. M. R. (2018). Importance of Improving Resilience in TeachingLearning Process of Students with Disabilities. International Research Journal of Management, IT and Social Sciences, 5(2), 120-128.

Olivar, A., \& Daza, A. (2007). Information and communication technology (ICT) and its impact on education in the 21st century. NEGOTIUM, 3(7), 21-46. Obtained from https://www.redalyc.org/pdf/782/78230703.pdf

Ortega, J., Vera, G., \& Burgos, M. (2003). Virtual reality and its educational possibilities. Etic @ net, 2(12), S / P.

Pérez, F. (2011). Creativity and Society (18), 1-39. Obtained from http://www.creatividadysociedad.com/articulos/16/4-Realidad\%20Virtual.pdf

Row, C. D. H. (1999). World Without End: Philip Hubert Frohman and the Washington National Cathedral (Doctoral dissertation, Harvard University).

Urquiza, L., Auria, B., \& Daza, S. (2016). Use of virtual reality, in the education of the future in educational centers in Ecuador. Science and Research, 1(4), 26-30. Retrieved from https://dialnet.unirioja.es/servlet/articulo?codigo=6118758

Zambrano, A. (2005). Ethical Aspects of the use of Virtual Reality in the Teaching of Human Anatomy. Fermentum, 15(44), 426-438. Obtained from https: // www. Present and Future of Virtual Reality Technology.redalyc.org/comocitar.oa?id=70504408 